\title{
Land Titling, Local Governance and Investment: An Empirical Investigation in Tanzania
}

\author{
Woubet Kassa ${ }^{1}$ \\ ${ }^{1}$ The World Bank, United States \\ Correspondence: Woubet Kassa, The World Bank, United States. E-mail: wkassa1@worldbank.org
}

Received: October 19, 2017

Accepted: December 5, 2017 Online Published: January 30, 2018

doi:10.5539/jsd.v11n1p56

URL: https://doi.org/10.5539/jsd.v11n1p56

\begin{abstract}
The role of property rights in resource allocation has been one of the central themes in development economics. Empirical clarity has been lacking; however, due to possible endogeneity of titles, unobserved heterogeneities and the non-experimental nature of the data. In addition, local political arrangements could encroach on the legitimacy and security that government titles provide. This study introduces new information that captures plot owners' (dis)approval of local governance structures and its implications on the titling-investment relationship. We find that titles will have the expected outcomes when there is higher level of approval of local administrative units by plot owners. Using the 2010/2011 Tanzania Living Standards Measurement Survey data, we show that the effects of titling on investment is positive and sizable. However, the investment return from titling is either negative or nonexistent when there is a higher level of disapproval of the local governing units by plot owners. Simply providing titles might not help investment without underlying changes in local governance and hence perceptions and legitimacy of local governance structures. Investment on land depends not on titling per se, but the future security titling might provide which in turn depends on the sense of approval (or disapproval) owners accord to the local the administrative structure and their functions.
\end{abstract}

Keywords: land titles, property rights, agriculture, governance, Tanzania, sub-Saharan Africa

\section{Introduction}

The role of property rights in resource allocation has been one of the central themes in development economics. There exist extensive theoretical arguments that property rights in land are closely associated with the allocative efficiency of agricultural resources and investment decisions. Various arguments have been forwarded to support the strong linkages between well-defined formal land rights and investment decisions. It is apparent that investment incentives depend on expectations of rights over the returns to that investment and hence on the nature of property rights (Goldstein and Udry, 2008). Individuals do not invest if the fruits of their investments are seized by others (Besley, 1995). Fear of expropriation could discourage long term investments on land. Land titles induce investment through improved access to credit through collateralization of land (Feder, 1988). Improved rights through titling simplify land exchanges and transactions, hence enabling the efficiency gains from trade and hence investment (Besley, 1995). Feder and Feeny (1991) also discuss the particular aspect of efficiency loss due to asymmetric information associated with insecure land tenure. In his most influential work The Mystery of Capital, De Soto (2000) explains why capitalism triumphs in the west and fails everywhere else: '... .because the rights ... are not adequately documented, these assets cannot readily be turned into capital, cannot be traded outside of narrow local circles where people know and trust each other, cannot be used as collateral for a loan, and cannot be used as a share against an investment.'

As a result, land titling or registration has emerged as a very popular policy prescription to enhance productivity and reduce poverty. With ownership officially documented and verified, the risk of challenges to ownership will be reduced, and the likelihood of having to incur high costs in defending one's possession of land will be lower. Incentives to invest will be enhanced, and land productivity will be increased (Feder and Nishio, 1998). However, empirical evidence has not been clear-cut. There is a predominant support for the notion that well defined property right structures enhance investment and hence increased agricultural production (Feder et al, 1988, Blarel, 1994; Gallinai and Schargodsky, 2010). Yet, whether formal land titling yields the expected results has been controversial particularly within the African continent. Titling has also been found to have no or very little impact on investment and productivity in many African countries (Atwood, 1990; Pinckney and Kimuyu, 1994; 
Bellemare, 2013)

The explanations for these seemingly conflicting findings are both methodological and conceptual. The identification of land titling effects is a difficult task because it typically faces the problem that formal property rights are endogenous (Galiani and Schargrodsky, 2010). For example, farmers may adopt strategies that involve investments in the form of boundaries or landmarks to reinforce security of rights to their plots. The allocation of property rights across households is not random but based on a set of distinguishing household and village level characteristics including the existing investment level on land, presence of legal instruments as well as other household and village unobservables. In addition, data on covariates of tilting (fixed investment) were often binary, reducing the likelihood of relating titling to continuous investment data (Smith, 2004). Binary choice model regressions provide less information and variation across subjects compared to their counterpart. Overall, empirical analysis has been complicated due to possible endogeneity of titles, unobserved hetrogeneities and the non-experimental nature of the data.

There are also conceptual arguments that put into question the soundness of the property rights paradigm. For example, the gains from trade or free exchange could be realized only in an efficient and free market, an unusual characteristic of most markets (including land) in particularly in many African countries. In addition, private property titling could fuel rent seeking (Loehr, 2012). Land registration can create rather than reduce uncertainty and conflict over land rights (Atwood, 1990). It might increase risks and transaction costs for certain numerically important groups, especially local people who rely on existing informal means to establish and safeguard their land claims (Atwood, 1990). This study is an attempt to direct attention and possibly address both the methodological and conceptual challenges in existing literature. The focus is on how the local governance structure expressed through land owner's (dis)approval of the structure affects the relationship between titles and investment on land.

To address the challenges associated with identification, we combine the use of an instrumental variable for titling with a fixed effects model. The literature in the choice of instruments ranges from those that use no instruments at all (e.g. Smith, 2004) to those who suggested multiple instruments (Besley, 1995). We adopt one of the four instruments suggested by Besley (1995). Another common approach is to adopt a province or district level proxy as an instrument such as the proportion of households with land titles (Do and Iyer, 2008) The challenge with these instruments, however is that they have different unit of analysis; province or district level, to that of the original variable, title ownership, which is a plot level characteristic. This is particularly problematic since the interest is in explaining differences in investment across plots with differing titles after controlling for other household variables. When a predominant number ${ }^{1}$ of households own more than a single plot with different title structures, the district level proxy is a poor instrument for land titling. Plots which are preferably located close to each other with different titling status, actually, provide a close to experimental analysis of the distinction in investment levels. Hence there is a need for plot specific instrumental variable. This study uses the inheritance status of a plot to instrument for the titling status of a plot. This is combined with village and household fixed effects to identify the relationship. This is further discussed in the empirical framework below.

The main value added of this study to existing literature is the consideration of the local institutional set up necessary for a title to establish security and the perception of security. Investments on a plot depends on security and the perceptions of security of the owner(s) on a specific plot. Traditional conceptions of rights ignore the intricate institutional settings that are necessary for a title or registration to reinforce notions of security over land. Goldstein and Udry (2008), for example, indicate that 'the intensity of investments on different plots ... corresponds to the individual's security of tenure, ..., in turn, the individual's position in the political hierarchy relevant to those particular plots'. Hence, just providing titles might not lead to significant improvements in security that yields greater investment returns. Boone $(2007,2015)$ note that outcomes of land tenure reform and modernization are predicated on the political choices, the extent of bureaucratization, secularization and democratization of political authority.

In our empirical analysis, we incorporate the role of these political structures at the local level on how titles enhance security and in turn investment. We use information on the ratings (approval or disapproval) provided by plot owners with respect to various local governing entities. By doing so, we expand the role of governance and local political structures from people associated with government officials (as in Goldstein and Udry (2008) to the general population. Arguably, households that accord higher legitimacy and approval to local governance institutions tend to reap more investment benefits from the titles than others. Because, these households feel more secure about titled land when they approve of the local administrative units and their administrative functions. One could argue that a higher approval represents association with the governing elites either directly 
or indirectly. To account for the institutional set up, we use information about the approval and disapproval status of various local governing entities by households including the village chairperson, village and ward executive officer, ward council, extension officer, the police chief and the member of parliament.

The rest of the paper is organized as follows. The next section presents the basic conceptual framework used in the study with the underlying theoretical framework. Section three details the empirical framework applied in the study. This is followed by section four which presents description of the data and section five which presents an overview of land tenure and titling in Tanzania. Section six presents discussion of the results followed by concluding remarks.

\section{Conceptual Framework}

Besley (1995) provides the underlying conceptual framework for analyzing the link between property rights and long term investment on land based on the three channels - the freedom from expropriation, access to credit and efficient reallocation of land resource. This study closely follows Besley's (1995) framework. Consider an individual making an investment decision on how much capital $\left(k_{t}\right)$ to invest at time $t$ on a given plot. The return from investment function for time $t+1 ; V_{t+1}$ depends on property rights, denoted by $R_{t+1}$ :

$$
\left.V_{t+1}=V\left(k_{t}\left(R_{t+1}\right), R_{t+1}\right)\right)
$$

Since tenure security could be driven by increased investment on the land, land right is considered endogenous ${ }^{2}$ and is given by the general equation where $R_{t+1}$ is increasing in $k_{t}$ :

$$
R_{t+1}=\psi\left(k_{t}, \Gamma\right)
$$

where $\psi$ represents the reverse effect of investment on land rights. $\Gamma$ represents all other factors that could potentially explain title ownership. Existing fixed investments on land may lead to titling of plots, hence establishing rights (Brasselle et al., 2002), as is a practice among farmers to invest on plots to ensure greater security. The return on investment is assumed to be increasing and concave in $k_{t}$. The cost of investment, that is increasing in $k_{t}$ and non-increasing in $R_{t+1}$ is given by:

$$
\left.C\left(k t\left(R_{t+1}\right), R_{t+1}\right)\right)
$$

The optimal investment choice satisfies the return (profit) maximizing condition of the farmer:

$$
\operatorname{Max} W\left(k_{t}, R_{t+1}\right) \equiv V\left(k_{t}\left(R_{t+1}\right), \psi\left(k_{t}\right)\right)-C\left(k_{t}\left(R_{t+1}\right), \psi\left(k_{t}\right)\right)
$$

From the optimization problem, it follows that investment increases as rights are improved. Solving the optimization yields an investment function that provides the framework for the empirical model in this study:

$$
k_{t}=\kappa\left(R_{t+1}\right)
$$

Though there is a strong theoretical framework to support the claim that improved land rights enhance investment, the claim that individual land titles through formalizing land rights drives investment has been found to be empirically fragile. Arguably, what might have been ignored in previous studies and in this framework, is the underlying institutional setting required for a title to ensure security and perceptions of security. To account for the institutional set up, we use information about the (dis)approval status of various local governing entities ${ }^{3}$ by households. Following this, the investment function could be modified to include this underlying local institutional framework $\left(L I F_{t}\right)$ that includes information about the approval and disapproval status of various local governing entities by households including the village chairperson, village and ward executive officer, ward council, extension officer, the police chief and the member of parliament. Hence, investment is a function of the property right on a plot conditional on existing political organization:

$$
k_{t}=v\left(R_{t} \mid L I F_{t}\right)
$$

Investment on land depends not on titling per se, but the future security titling might provide. This in turn depends on the local institutional framework and the sense of legitimacy plot or title owners accord to the administrative structure and their functions.

\section{Empirical Framework}

The basic empirical strategy follows a baseline plot-level regression model given by:

$$
y_{i j}=f\left(R_{i j}, P_{i j}, X_{i,} \varepsilon_{i j}\right)
$$

Where $y_{i j}$ is the investment level undertaken by household $i$ on plot $j$; $R_{i j}$ is the property right status of plot $j$ within household $I ; P_{i j}$ is a set of plot specific characteristics; $X_{i}$ is a set of household characteristics and $\varepsilon_{i j}$ is the stochastic component. In the ideal setting of an experimental design, the treatment group comprises of plots of land that are randomly titled. Hence, simple testing of the difference in investment behavior between titled and 
non-titled plots would yield the required results. This would however require repeated observations of randomly assigned titles and their counterpart plots across several villages and over a relatively longer time period. The data set used in this study is only cross-sectional. And, it is hardly possible that land titles are randomly assigned. It is possible that the plots in a given village are more likely to be titled than in other villages. Or, more importantly, households who seek titles could be systematically different from those who don't. To account for these systematic differences, various controls are used both at the household and plot level including wealth status of household, distance to market from the plot, soil quality, steepness of plot and others. Controlling for these characteristics helps the identification of the effects of land titles on farmers' investment behavior. Hence the original model will be estimated after controlling for household and plot level characteristics:

$$
y_{i j k}=\alpha+\phi_{k} X_{i}+\varphi k R_{i j}+\gamma k P_{i j}+\varepsilon_{i j}
$$

However, the inclusion of the controls provides only a limited solution leaving a concern that measured rights might also proxy for omitted variables such as the village political structure, farmers' investment ability or knowledge. The distribution of land titles runs across administrative procedures. The implementation of the titling program differs across various regions in a country. Land titles are applied in different periods of time in various regions. The extent of tenure security availed by the titles also differs based on local administrative factors such as the extent of elite capture, recent history of tenure security and the level of trust/security a title provides. This would bias the estimates of (5) and one could only find a spurious link between land rights and investment. Without controlling for these village specific fixed effect, one would expect to see differential effects of land titles on investment. The village fixed effect may also represent other time invariant variables. In Tanzania, the survey identifies 26 administrative regions (villages). The following model is estimated with village level fixed effects $\left(\delta_{k i}\right)$ :.

$$
y_{i j k}=\delta_{k i}+\phi_{k} X_{i}+\varphi_{k} R_{i j}+\gamma_{k} P_{i j}+\varepsilon_{i j}
$$

Though this method yields a better relationship between titling and investment, there are still concerns with establishing actual causality between land titling and investment. Because, the identification of land titling effects in this framework is difficult due to the fact that land titles might be endogenous. In fact, a reverse causation has commonly been suggested in which investments on a plot of land can possibly secure the owner's right to the land For example, households could invest in infrastructure as well as tree boundaries to secure their tenure. To account for the endogeneity of land rights or titling, the following empirical model is estimated with instrumental variables (IV) method. This framework also includes the political setting captured by the perception of land owners about local governing structures $L I F_{t}$. The main interest, however is not on the impact of the perception of the plot owners about local administrative structures on investment. Rather, the interest is on the impact of the owners' perception on the relationship between titling and investment. To address this, the titling status of a plot interacts with the perception indicator in the final empirical model. This provides an alternative framework for the village fixed effects model where perceptions about local governing structures can be explicitly controlled for.

$$
\begin{gathered}
y_{i j k}=\delta_{k i}+\phi_{k} X_{i}+\varphi_{k} R_{i j}+\gamma_{k} P_{i j}+\kappa L I F_{t}+\tau R_{i j} * L I F_{t}+\varepsilon_{i j} \\
R_{i j}=\sigma_{i j}+\phi Z_{i j}+\eta_{i j}
\end{gathered}
$$

Where, $Z_{i j}$ is the instrumental variable for the ownership of a formal title of ownership for plot $j$ by household $i$. Finally, we will mix the fixed effects (FE) model with the IV model to address the issues of both endogeneity and unobserved heterogeneity simultaneously.

Given the above specification, there is a need to employ an efficient instrument for titling status that is exogenous and relevant. Besley (1995) suggested four possible instruments of property rights: $(i$.) Whether there is a transfer deed, (ii.) Whether the household has ever litigated over its right to the field, (iii.) How the field was acquired, (iv.) How many years the field has been owned. The fourth IV fails to satisfy the externality/exogeneity assumption, since the number of years the plot has been owned determines the already existing level of investment on the land. The first and third IV would be valid if how the field is acquired is independent of investment.

Using a mix (i.) and (iii.), we use the inheritance status of the plot as an instrument for the titling status of the plot. The inheritance status variable provides an exogenous source of variation that determines the probability of seeking to have a land titled or not. The underlying assumption is that it is external to the investment decision on that specific plot. But how the plot is acquired would affect the likelihood of seeking to have a title. A simple regression of land title status on inheritance status indicates strong possible association between the two variables, hence satisfying the 'relevance' (Greene, 2012) assumption. Two stages least squares (2SLS) method 
will be employed to estimate the instrumental variable model given in equations 10 .

\section{Data}

The study uses the 2010/2011 Tanzania Living Standards Measurement Survey; a nationally representative household survey that collected information on a wide range of topics including agricultural production, non-farm income generating activities, and a wealth of other household characteristics. Information is collected at a plot level. Farmers were asked about the size and number of plots and titles they possessed and the usage of plots. Information on the main crop cultivated, decisions on which crop to cultivate, soil type and quality as well as the steepness of plot were also collected. Besides, there is information on the number of permanent crops and trees planted on each plot. Unlike many other surveys, there is information on the titling status of each plot, even within the same household.

The dependent variable used to proxy for fixed investment is the number of trees or permanent crops per acre on each plot. Considering the per acre investment rather than the total investment helps account for variations due to size of plot. These include the planting of trees, either fruit or otherwise, and permanent crops that take relatively many years to yield output. Tree planting has been the preferred proxy for fixed investment (Besley, 1995; Smith, 2004; Bandiera, 2007; Bellemare, 2010). A continuous measure of the number of trees planted is used as the dependent variable. This eases the challenges associated with using a binary variable for whether investment has been undertaken or not. Since planting of trees and permanent crops might not be the appropriate investment choice for households in urban areas, the study will only focus on rural households. We use additional investment indicators such as fallowing and planting of distinct types of trees to check robustness of our results. We identify the effect of land titles on investment using plot level, household level and community level characteristics. Household level characteristics include the demographic structure of the household, education of adults in the household, the main occupation of the head, as well as the wealth index as a proxy for the economic status of the household. Plot level characteristics used in the study are primarily the specific feature of the plot in terms of soil quality, steepness of plot, and proximity to markets.

Table A1 in the appendix presents summary statistics with mean comparison tests between plots with title and plots without title to investigate potential differences between the two groups. There is no significant difference in their demographic composition of households that own titled plots. Similarly, there are no differences in plot characteristics except the number of plots owned. Households that own higher number of plots are more likely to own titled plots. The fundamental similarity between the groups might indicate that the allocation of titles is exogenous. However, in all measures of educational attainment including average household education, education level of the head and the highest education level in the household, more educated households are more likely to own titled plots.In addition, farmers tend to plant more trees in general and permanent trees in particular compared to untitled plots. Households that own titled plots tend to be wealthier. At least by most of the governance indicators, households with titled plots tend to attach a more positive outlook towards various levels of local government compared to their counterpart. These results, however, are only preliminary. The next section delves deeper into the empirical analysis and results after accounting for additional factors and undertaking proper identification strategies.

\section{Land Tenure and Titling in Tanzania}

Before Tanzania was colonized by the Germans and then the British, the general structure of landholding was based on traditional law and culture of each respective tribe in different locations (National Land Planning, URT, NLP, 1997). These continued through the colonial era though they were limited by the newly introduced German and British land tenure system under which all lands were declared to be crown and public lands respectively. After independence, the President, Julius Nyerere, introduced African Socialism, an initiative that transferred the customary land rights of ethnic groups and clans to newly elected village councils and encouraged collective cultivation of the land. The customary land tenure is still in place, but the chiefs, headmen and elders have been replaced by elected village councils. In 1985, with the advent of a new leadership, there was a consensus that existing laws did not foster greater investment and sound allocation and administration of land. Preference for individually allocated and individually cultivated farmland was strong leading to the National Land Policy of 1995 and 1999.

Tanzania's current legal framework and procedures governing land were adopted between 1994 and 2004. It was laid out in the two new Land Acts: The National Land Policy 1995 and the Village Land act 1999 (URT 1999a+b), which became operational in May 2001. The policy behind these acts is the National Land Policy of 1995 (URT 1995) that set out the fundamental principles guiding land rights and management. The emphasis is on the fundamental principles covering the following key areas: Land ownership rights; land use principles; land 
administration; participation; and gender considerations (URT, Year). The approach involved a gradual transition to a legal framework that supports private property rights (while still granting the President ultimate authority over all land), permits individualized (rather than collective) control of resources in farming areas, and promotes private investments that utilize Tanzanias natural resources for economic gain (USAID, 2011). Accordingly, land is divided into three categories: General Land, Reserve Land, and Village Land (policy Document). Land management and administration is largely decentralized to local administration (Policy). General Land is governed by the Land Act and directly under the Commissioner, Reserve Lands under statutory or other bodies set up with the powers over these lands and village land (which accounts for about $90 \%$ of the land) is governed by the Village Land Act and under the administration of the village council (Shivji 1999). The principle is that the Village Council administers the land through the authority of the Village Assembly - the highest authority at the village level. (Wily 2003, Shivji 1999, Odgaard and Bentzon (in print), Sundet 2005). The Village Land Act further divides village land into the following types: 1) communal and public use land, 2) individual or family or group land over which landownership titles may be issued, 3) Reserved land - land reserved for future communal or individual use (Wily 2003).

One of the main advantages of the 1999 legislation is the move to legally secure customary land rights. The following different tenure forms were identified in all parts of the field area: $i$. customary rights of occupancy: Villagers have a customary right of occupancy for village land that they hold under customary law or have received as an allocation from the village council. Customary rights of occupancy can be held individually or jointly, are perpetual and heritable, and may be transferred within the village or to outsiders with permission of the village council (GOT Village Land Act 1999b, USAID, 2011). Usually customary rights are associated with rights of use of the land (ibid.). The Land Act (Art. 4(3)) recognizes customary rights of occupancy even if the land is not registered and the landholder has no certificate for the landEvery person lawfully occupying land, whether under a right of occupancy wherever that right of occupancy was granted or deemed to have been granted, or under customary tenure, deemed to occupy and has always occupied that land, the occupation of such land shall be deemed to be property...

While the Land Act recognizes undocumented customary tenure as equal to statutory tenure, the Village Land Act provides ways for villagers to locally register their rights and obtain certificates as evidence of that ownership (at the village and household level) (Alden Wily, 2003). A significant amount of Village Land has not been registered and many villagers do not hold certificates (TFWG, 2009; Malimbwi, 2011). The Village Land Act and accompanying Village Land Regulations of 2001 establish complicated and costly processes to register Village Land which villagers have difficulty completing. ${ }^{4}$ For example, the Regulations provide for 50 different written forms for administering Village Land (Alden Wily, 2003; Sundet, 2005). ii. Granted right of occupancy: are available for general and reserved land, subject to any statutory restrictions and the terms of the grant. Grants are available for periods up to 99 years and can be made in periodic grants of fixed terms. Granted land must be surveyed and registered under the Land Registration Ordinance and is subject to annual rent. Squatters and others without granted rights may have customary rights to occupy general land, which may be formalized with a residential license or remain unformalized and insecure (GOT Land Act 1999a; Maoulidi 2006). iii.Leaseholds: are derivative rights granted by holders of granted or customary rights of occupancy. Holders of registered granted rights of occupancy may lease that right of occupancy or part of it to any person for a definite or indefinite period, provided that the maximum term must be at least ten days less than the term of the granted right of occupancy. Holders of customary rights of occupancy may lease and rent their land, subject to any restrictions imposed by the village council (GOT Land Act 1999a). $i v$. Residential license: is a derivative right granted by the state (or its agent) on general or reserved land. Residential licenses may be granted for urban and peri-urban non-hazardous land, including land reserved for public utilities and for development.

Table A2 presents the various types of land titles observed in the data. many of the title categories indicated in the official policy document are well represented in our data set. Most can be categorized into the first two categories discussed above in the policy document, i.e. granted rights of occupancy and customary rights of occupancy as well as village government and court documents of title. Much of the titles are either certificates of customary or granted right of occupancy, or certificates of allocation from the local government. The importance of local governance looms large in titling, security and investment since land administration is highly decentralized in this particular case. This underscores the importance of accounting for local governance structures in examining the relationship between titles and investment on land.

\section{Discussion}

To identify the impact of land titles on long term investment, we estimate models with the number of trees planted per acre as the dependent variable on title ownership and other plot, household and community level 
information. Tables 1 and 2 summarize results of estimation based on models 7-10. Table 3 presents results using traditional OLS and fixed effects while Table 4 reports results based on the method of IV. Preliminary results corresponding to the main hypotheses seem to suggest that, the titling status of a plot matters significantly in long term investment decisions. However, this is only true if we ignore the governance or political settings in the community. Column 1 in Table 1 shows that, without any consideration to the local governance framework, titling seems to enhance investment. This is in line with most existing literature including Besley (1995) in Ghana; Place and Otsuka (2001) in Malawi; Gavian and Fafchamps (1996) in Niger; Newman et al. (2015) and Markussen (2015) in Vietnam. Columns 2, 3 and 4 from Table 1 include the disapproval ratings of households with respect to the job of the head of the village and its interaction term with title status of a plot. Taking account of the local administrative variables, we seldom find a positive return from investing. This is also confirmed with the fixed effects model which controls for household fixed effects including household's interaction with local administrative units. Title ownership does have no significant bearing in enhancing investment if households don't confer higher approval to the activities of the existing governance structure. The missing link in the title-investment relationship is the local institutional framework and the perceptions of plot owners with respect to their role and actions. In other words, titling will have the expected impact for those households, that for some reason, tend to favor the functions of the village head. As indicated previously, this relationship between titling and investment might have been biased due to the endogeneity of titling. To address this, IV models are estimated and variants of the estimation results are presented in Table 2.

Results from Table 2 address issues of endogeneity and also checks for robustness. Providing land certification seems to have a strong positive economic impact in terms of increasing long term investment as shown in the results from model IV1. After controlling for local governance structures, however, these positive returns disappear. Only households with positive association with the local administrative units and their functions register positive returns. After controlling for titles, households with higher levels of average education tend to invest more in permanent trees. Owners of plots very close to market centers tend to invest less on long term crops or trees. This might be due to their focus on crops with faster returns such as cash crops with short maturity. It might seem counter-intuitive that fewer number of trees are planted on flatter plots. However, it is more reasonable to presume that more suitable and flatter plots are used for the production of recurrent and staple crops.

These findings are robust to various specifications. Inclusion and exclusion of various household and plot level characteristics did not change the results. Variations of the instrumental variable model estimates also show that certification of land through titles matters significantly in investment decisions only if we ignore the local political settings. However, the investment returns from titling is nonexistent when there is a higher level of disapproval of the local governing elites by plot owners. Simply providing titling might not help investment without underlying changes in local governance and perceptions and legitimacy of local governing entities. Investment on land depends not on titling per se, but on the future security titling might provide which in turn depends on a sense of approval (or disapproval) owners accord to the administrative structure and their functions.

Our findings do not fully reject the property rights paradigm that improved tenure security through formal titles enhances fixed investments. Land titles, through improved security, could enhance investment. However, this result holds for those plot owners who, for various reasons, perceive the local political elites positively. This may indicate that, the empirical challenge of understanding the relationship between property rights and investment is attributed largely to an understatement of the local political settings that might perverse the positive returns from investment. Titling programs might also fuel rent seeking, reinforce elite capture and raise the risks for local people who might be better off on existing informal titling structures (Atwood, 1990; Loehr, 2010). In a narrow definition of political elites, Goldstein and Udry (2008) show that plot owners associated with others in the offices of social or political power enjoy greater security and investment. This study extends this argument. Plot owners that view the local administrative machinery positively tend to enjoy a rise in security due to titles, and hence increased investment. The outcomes of land registration programs depend on the governance environment. Land registration programs should be complemented (or even better preceded) by a heedful assessment of the local governance institutions and social interactions between citizens and the governing elites. 
Table 1. OLS Model with and without governance indicators

\begin{tabular}{|c|c|c|c|c|}
\hline \multicolumn{5}{|c|}{ Dependent variable: Trees per Acre on each plot } \\
\hline VARIABLES & OLS1 & OLS2 & OLS3 & $\mathrm{FE}$ \\
\hline \multirow[t]{2}{*}{ Title Ownership } & $29.55^{*}$ & 65.91 & 63.38 & -43.03 \\
\hline & $(17.51)$ & $(48.99)$ & $(48.57)$ & $(153.8)$ \\
\hline \multirow[t]{2}{*}{ Female Head } & -1.182 & -0.880 & 4.959 & \\
\hline & $(16.68)$ & $(18.44)$ & $(18.58)$ & \\
\hline \multirow[t]{2}{*}{ Age of Head } & -0.516 & -0.459 & -0.305 & \\
\hline & $(0.435)$ & $(0.488)$ & $(0.531)$ & \\
\hline \multirow[t]{2}{*}{ Education, adult } & $4.681 * *$ & $5.863 * *$ & 3.687 & \\
\hline & $(2.315)$ & $(2.554)$ & $(2.685)$ & \\
\hline \multirow[t]{2}{*}{ Size of hh } & -0.274 & 0.283 & 0.0952 & \\
\hline & $(1.938)$ & $(2.206)$ & $(2.233)$ & \\
\hline \multirow[t]{2}{*}{ Value of agriculture asset } & & $-3.54 \mathrm{e}-06^{*}$ & $-3.35 e-06^{*}$ & \\
\hline & & $(1.82 \mathrm{e}-06)$ & $(1.79 \mathrm{e}-06)$ & \\
\hline \multirow[t]{2}{*}{ Disapproval of Village Head } & & -7.085 & -9.563 & \\
\hline & & $(10.86)$ & $(10.98)$ & \\
\hline \multirow[t]{2}{*}{ Title $\times$ Disapproval } & & -24.92 & -22.56 & 7.844 \\
\hline & & $(26.45)$ & $(26.16)$ & $(75.44)$ \\
\hline \multirow[t]{2}{*}{ Plot Slope (flat) } & & $-38.22 * * *$ & $-49.49 * * *$ & 52.87 \\
\hline & & (13.58) & $(13.87)$ & $(32.16)$ \\
\hline \multirow[t]{2}{*}{ Soil Quality (above average) } & & -8.349 & -14.84 & -82.23 \\
\hline & & $(25.80)$ & $(25.85)$ & $(53.31)$ \\
\hline \multirow[t]{2}{*}{ Distance to market } & $-0.868 * *$ & $-0.954 * *$ & $-0.824 *$ & -2.803 \\
\hline & $(0.385)$ & $(0.418)$ & $(0.427)$ & $(2.684)$ \\
\hline \multirow[t]{2}{*}{ Years of plot ownership } & & & -0.367 & -0.0836 \\
\hline & & & $(0.316)$ & $(0.813)$ \\
\hline District (Dummies) & Yes & No & Yes & \\
\hline \multirow[t]{2}{*}{ Constant } & $157.2 * * *$ & $155.2 * * *$ & $225.9 * * *$ & $212.3^{* * *}$ \\
\hline & $(32.14)$ & $(49.80)$ & $(51.90)$ & $(72.03)$ \\
\hline Observations & 1,517 & 1,331 & 1,245 & 1,248 \\
\hline R-squared & 0.032 & 0.022 & 0.047 & 0.786 \\
\hline
\end{tabular}


Table 2. IV Model with and without governance indicators

\begin{tabular}{|c|c|c|c|c|}
\hline \multicolumn{5}{|c|}{ Dependent variable: Trees per Acre on each plot } \\
\hline VARIABLES & IV1 & IV2 & IV3 & IV4 \\
\hline \multirow[t]{2}{*}{ Title Ownership } & $64.86^{*}$ & 122.4 & 166.0 & 141.0 \\
\hline & (38.99) & $(105.8)$ & $(115.3)$ & $(114.8)$ \\
\hline \multirow[t]{2}{*}{ Female Head } & -2.423 & 0.682 & -0.0556 & 3.449 \\
\hline & $(15.80)$ & $(16.80)$ & $(18.41)$ & $(18.23)$ \\
\hline \multirow[t]{2}{*}{ Age of Head } & -0.428 & -0.567 & -0.495 & -0.615 \\
\hline & $(0.422)$ & $(0.444)$ & $(0.492)$ & $(0.488)$ \\
\hline \multirow[t]{2}{*}{ Education, adult } & 3.066 & $5.370^{* *}$ & $5.640^{* *}$ & $4.400 *$ \\
\hline & $(2.293)$ & $(2.338)$ & $(2.576)$ & $(2.575)$ \\
\hline \multirow[t]{2}{*}{ Size of hh } & -2.423 & 0.0792 & 0.130 & 0.365 \\
\hline & $(2.017)$ & $(1.989)$ & $(2.206)$ & $(2.203)$ \\
\hline \multirow[t]{2}{*}{ Value of agriculture asset } & $-3.53 \mathrm{e}-06^{*}$ & $-3.36 \mathrm{e}-06^{* *}$ & $-3.43 e-06^{*}$ & $-3.43 e-06^{*}$ \\
\hline & $(1.83 \mathrm{e}-06)$ & $(1.71 \mathrm{e}-06)$ & $(1.82 \mathrm{e}-06)$ & $(1.80 \mathrm{e}-06)$ \\
\hline \multirow[t]{2}{*}{ Disapproval of Village Head } & & -2.345 & 1.117 & 0.644 \\
\hline & & $(13.14)$ & $(14.73)$ & $(14.70)$ \\
\hline \multirow[t]{2}{*}{ Title $\times$ Disapproval } & & -21.69 & -70.11 & -59.65 \\
\hline & & $(60.95)$ & $(65.68)$ & $(65.43)$ \\
\hline \multirow[t]{2}{*}{ Plot Slope (flat) } & $-43.56 * * *$ & & $-38.45 * * *$ & $-45.13 * * *$ \\
\hline & $(12.12)$ & & $(13.55)$ & $(13.47)$ \\
\hline \multirow[t]{2}{*}{ Soil Quality (above average) } & -14.10 & & -6.557 & -5.344 \\
\hline & $(22.32)$ & & $(25.82)$ & $(25.53)$ \\
\hline \multirow[t]{2}{*}{ Distance to market } & $-1.225 * * *$ & & $-0.950 * *$ & $-0.883 * *$ \\
\hline & $(0.408)$ & & $(0.417)$ & $(0.416)$ \\
\hline District (Dummies) & No & No & Yes & Yes \\
\hline \multirow[t]{2}{*}{ Constant } & $183.5^{* * *}$ & $101.5^{* * *}$ & $139.1 * * *$ & $194.4 * * *$ \\
\hline & $(39.63)$ & $(38.42)$ & $(53.58)$ & $(54.10)$ \\
\hline Observations & 1,818 & 1,517 & 1,331 & 1,331 \\
\hline R-squared & 0.016 & 0.005 & 0.019 & 0.044 \\
\hline
\end{tabular}

Standard errors in parentheses

$$
* * * \mathrm{p}<0.01, * * \mathrm{p}<0.05, * \mathrm{p}<0.1
$$

\section{Conclusion}

Previous studies find conflicting results on the effect of titling on fixed investment. This study adopts econometric tools to control for the endogeneity of land titles and unobserved heterogeneity to find the impacts of land titling on investment. We also incorporate the importance of local information about the interaction 
between households and local governing entities using plot owners' ratings. Using the 2010/2011 Tanzania National Survey data, the results do not show a significant positive relationship between titling and long term investment as measured by the number of trees and permanent crops planted on a plot. Plot owners exhibit increased investment returns due to formal title only if they accord greater positive ratings to the local village heads or administrative units.

This study is an improvement from previous literature in two ways. First, it introduces a more reliable instrument for titling that yields consistent estimates with the fixed effects model. Second, it introduces new information in the form of plot owners' approval of local administrative units to underscore the significance of local social and political interactions to better understand the titling-investment relationship. It also takes advantage of the continuous measure of fixed investment: number of permanent crops and trees planted on a plot in contrast to using a discrete measure of whether there is investment or not.

The results suggest that the empirical challenge in identifying the effects of property rights on investment is attributed largely due to an essential information that ensures security of titles, i.e. the local governance factor. Results show that simply providing titles might not enhance investment indiscriminately. It should be emphasized that further policy actions should consider the importance of governance and political administration in programs involving land registration and titling. The study suggests that government actions in similar African countries that improve tenure security through titles can significantly enhance investment and further economic activity, but only after due consideration to the governance and administration of the program as well as overall administration.

\section{References}

Atwood, D. A. (1990). Land registration in Africa: The impact on agricultural production. World development, 18(5), 659-671. https://doi.org/10.1016/0305-750X(90)90016-Q

Bandiera, O. (2007). Land tenure, investment incentives, and the choice of techniques: Evidence from Nicaragua. The world bank economic review, 21(3), 487-508. https://doi.org/10.1093/wber/lhm005

Bellemare, M. F. (2010). The productivity impacts of de jure and de facto land rights.

Bellemare, M. F. (2013). The productivity impacts of formal and informal land rights: Evidence from Madagascar. Land Economics, 89(2), 272-290. https://doi.org/10.3368/le.89.2.272

Besley, T. (1995). Property rights and investment incentives: Theory and evidence from Ghana. Journal of Political Economy, 103(5), 903-937. https://doi.org/10.1086/262008

Boone, C. (2007). Property and constitutional order: Land tenure reform and the future of the African state. African Affairs, 106(425), 557-586. https://doi.org/10.1093/afraf/adm059

Boone, C. (2015). Land tenure regimes and state structure in rural Africa: implications for forms of resistance to large-scale land acquisitions by outsiders. Journal of Contemporary African Studies, 33(2), 171-190. https://doi.org/10.1080/02589001.2015.1065576

Brasselle, A.-S., Gaspart, F., \& Platteau, J.-P. (2002). Land tenure security and investment incentives: puzzling evidence from Burkina Faso. Journal of Development Economics, 67(2), 373-418. https://doi.org/10.1016/S0304-3878(01)00190-0

De Soto, H. (2000). The mystery of capital: Why capitalism triumphs in the west and fails everywhere else.

Do, Q.-T., \& Iyer, L. (2008). Land titling and rural transition in Vietnam. Economic Development and Cultural Change, 56(3), 531-579. https://doi.org/10.1086/533549

Feder, G. (1988). Land policies and farm productivity in Thailand. Johns Hopkins University Press.

Feder, G., \& Feeny, D. (1991). Land tenure and property rights: Theory and implications for development policy. The World Bank Economic Review, 5(1), 135-153. https://doi.org/10.1093/wber/5.1.135

Feder, G., \& Nishio, A. (1998). The benefits of land registration and titling: economic and social perspectives. Land use policy, 15(1), 25-43. https://doi.org/10.1016/S0264-8377(97)00039-2

Galiani, S., \& Schargrodsky, E. (2010). Property rights for the poor: Effects of land titling. Journal of Public Economics, 94(9), 700-729. https://doi.org/10.1016/j.jpubeco.2010.06.002

Goldstein, M., \& Udry, C. (2008). The profits of power: Land rights and agricultural investment in ghana. Journal of political Economy, 116(6), 981-1022. https://doi.org/10.1086/595561

Loehr, D. (2012). Capitalization by formalization? -challenging the current paradigm of land reforms. Land Use 
Policy, 29(4), 837-845. https://doi.org/10.1016/j.landusepol.2012.01.001

Pinckney, T. C., \& Kimuyu, P. K. (1994). Land tenure reform in east Africa: good, bad or unimportant? Journal of African Economies, 3(1), 1-28. https://doi.org/10.1093/oxfordjournals.jae.a036794

Smith, R. E. (2004). Land tenure, fixed investment, and farm productivity: Evidence from Zambia's southern province. World Development, 32(10), 1641-1661. https://doi.org/10.1016/j.worlddev.2004.05.006

\section{Notes}

Note $1.47 \%$ of the households in our sample under study own more than a single plot.

Note 2 . This is the popular endogeneity problem associated with land titling. However, endogeneity could as well be either due to selection or other omitted variables.

Note 3. This information includes plot owners' evaluation of the village chairperson, village and ward executive officer, ward council, extension officer, the police chief and the member of parliament. This information is collected by the survey used in the study.

Note 4. The significant difference in the levels of education 


\section{Appendix A}

Table A1. Summary Statistics, Mean Comparison between Titled and Untitled Plots

\begin{tabular}{lrr|rr|r}
\hline & Titled Plots (N=284) & No Titles (N=1699) & \\
\hline VARIABLES & Mean & Std. Dev. & Mean & Std. Dev. & Diff. \\
\hline Trees per acre & 138.851 & 254.981 & 100.391 & 250.534 & $38.460^{* *}$ \\
Female Head & 0.153 & 0.33 & 0.177 & 0.381 & -0.023 \\
Age of Head & 51.842 & 14.664 & 49.595 & 14.739 & $2.247^{* *}$ \\
Education of Adults & 5.628 & 3.314 & 5.038 & 2.531 & $0.590^{* * *}$ \\
Household Size & 6.363 & 3.498 & 6.376 & 3.286 & -0.013 \\
Household Labor & 3.084 & 1.558 & 3.114 & 1.857 & -0.03 \\
Male Labor & 1.553 & 1.022 & 1.556 & 1.259 & -0.003 \\
Female Labor & 1.53 & 0.959 & 1.558 & 1.022 & -0.028 \\
Agricultural Assets & 420000 & 2204713 & 680000 & 4505229 & -260000 \\
Disapproval of Village Head & 1.693 & 0.751 & 1.811 & 0.683 & $-0.118^{* *}$ \\
Disapproval x title & 1.693 & 0.751 & 0 & 0 & $1.693^{* * *}$ \\
Plot slope1 & 0.529 & 0.501 & 0.495 & 0.5 & 0.034 \\
Soil quality (above average) & 1.069 & 0.258 & 1.076 & 0.256 & -0.008 \\
Distance of Plot to Market & 9.778 & 16.341 & 10.806 & 15.885 & -1.028 \\
Years Plot Owned & 25.777 & 25.952 & 23.736 & 23.499 & 2.041 \\
Plot Size & 1.046 & 1.119 & 0.981 & 1.291 & 0.065 \\
\hline
\end{tabular}

Table A2. Types of Title in Data

\begin{tabular}{l|rr}
\hline Type of Title & Frequency & Percent \\
\hline Granted Right of Occupancy & 30 & 10.56 \\
Certificate of Customary Right of Occupancy & 47 & 16.55 \\
Residential License & 4 & 1.41 \\
Village-government-witnessed Purchase Agreement & 46 & 16.2 \\
Local-Court-Certified Purchase Agreement & 10 & 3.52 \\
Inheritance Letter & 67 & 23.59 \\
Letter of Allocation from Village Government & 67 & 23.59 \\
Other Government Document & 1 & 0.35 \\
Official Correspondence & 4 & 1.41 \\
Utility or Other Bill & 8 & 2.82 \\
\hline
\end{tabular}

\section{Copyrights}

Copyright for this article is retained by the author(s), with first publication rights granted to the journal.

This is an open-access article distributed under the terms and conditions of the Creative Commons Attribution license (http://creativecommons.org/licenses/by/4.0/). 